\title{
IMPROVING ATTITUDES TOWARD BRANDS WITH ENVIRONMENTAL ASSOCIATIONS: AN EXPERIMENTAL APPROACH
}

\author{
Francisco J. Montoro Rios ${ }^{1}$ \\ Teodoro Luque Martínez \\ Francisca Fuentes Moreno \\ Paloma Cañadas Soriano
}

Francisco J. Montoro Rios is an Associate Professor of Marketing. Teodoro Luque Martínez is a Professor of Marketing. Francisca Fuentes is an Asociate Professor of Marketing. Paloma Cañadas Soriano is an Associate Professor in Marketing. All authors are members of the faculty at the College of Economics and Business Administration, University of Granada, Spain.

KEYWORDS: environmental claims, environmental information processing, commerce and environment, environmental labeling programs, brand attitude.

\section{RESEARCH PAPER}

\section{STRUCTURED ABSTRACT:}

\section{Purpose}

To determine the relative importance of the ecological attribute when other attributes referring to the functional performance of a brand are taken into account, and check the effectiveness of environmental labels.

\section{Design/methodology/approach}

We have established an experiment in which 352 women responsible for the household shopping are exposed to different levels of environmental information. We analyze the

\footnotetext{
${ }^{1}$ Contact with the authors: fmontoro@ugr.es;
} 
effect said information has on product attitude and purchase intention. In order to transmit the information, a leaflet specifically designed for the research was used.

\section{Findings}

This study confirms the presence of a positive effect of environmental associations on brand attitude, though this effect is smaller than that of other functional attributes. We also demonstrate that using independent environmental certifications strengthens beliefs in the product's ecological performance.

\section{Research limitations/implications}

The use of washing powder can limit the feasibility of extrapolation of the results to other products. Therefore, a replication in other product categories is necessary / advisable.

\section{Practical implications}

In the light of the results, using environmental associations certified by independent bodies is recommended. This would help improve both brand attitude and brand equity.

\section{Originality/value}

This paper increases the knowledge about the precise commercial usefulness of environmental associations in relation with other attributes. 


\section{IMPROVING ATTITUDES TOWARD BRANDS WITH ENVIRONMENTAL ASSOCIATIONS: AN EXPERIMENTAL APPROACH}

KEYWORDS: environmental claims, environmental information processing, commerce and environment, environmental labeling programs, brand attitude.

\section{RESEARCH PAPER}

ABSTRACT: There is great uncertainty regarding the potential of environmental attributes in improving brand attitude. This study analyzes the relative importance of the ecological attribute when other attributes referring to the functional performance of the brand are taken into account. In addition to this, we put forward an experimental design to check the effectiveness of environmental labels in evaluating the environmental attribute and in reducing the uncertainty concerning said evaluation. Our study ratifies the presence of a positive effect of environmental associations on brand attitude, though this effect is lower than that of other functional attributes. We also demonstrate that using independent certifications strengthens beliefs in the product's ecological performance. In the light of the results, using environmental associations certified by independent bodies is recommended. This would help improve both brand attitude and brand equity. However, a greater effort is needed to ensure that the consumer is capable of recognizing environmental labels.

\section{INTRODUCTION}

The late 1960s and early 1970s saw the start of a growing interest in the environment and in the possible ways of improving it. Thus, and in spite of differences among countries, over $75 \%$ of the citizens in the major developed and developing nations claim to be very, or relatively, concerned about the environmental situation [1]. In line with this, and bearing in mind that marketing is a discipline that is mainly guided by the economic, technological, 
political and social context (Sheth and Sidosia 1999), the field of marketing has produced numerous studies since the start of the 1970s. These have mostly concentrated on analyzing the effect of environmental concern on consumer decisions, given the varying levels of success that the different business strategies based on the protection of our natural surroundings have had.

In an attempt to shed some light on the causes of the limited acceptance of environmentally-advantageous products, we have analyzed the way in which consumers use environmental information in their purchase decisions. More specifically, the main objective of this study is to analyze the role environmental attributes play in the forming of brand attitudes. To do this, we have established an experiment in which 352 women responsible for the household shopping are exposed to different levels of environmental information. We analyze the effect said information has on product attitude and purchase intention.

\section{LITERATURE REVIEW}

Knowledge about the power of brands in influencing purchase and consumer decisions is an aspect that is of great interest to marketing researchers and professionals. This power is embodied in the concept of brand equity. According to Aaker (1992), brand equity is formed by, among other aspects, perceived quality and brand associations. These associations are, in short, all those links created by the firm's efforts to communicate with the public (Van Osselaer and Janiszewski 2001).

Keller (1993, 1998b) divides brand associations into attributes, benefits and attitudes. Thus, if we place these classifications on an ascending scale, environmental associations can be considered firstly as attributes, in that the consumer uses these beliefs in the product's environmental performance to characterize the brand. These attributes can be considered as product-related (Keller 1993) (environmentally-friendly chemical 
composition) or non-product-related (beliefs in the possibility of packaging recycling or in the overpricing of environmentally-marketed products).

Moving up the scale, these associations can act as consumer-expected benefits if the individual believes that the product can help the environment. The environmental benefits attributed to brands could operate on the three levels described by Park, Jaworski, and Macinnis (1986). Thus, these benefits can be related to the good performance of the product (functional benefit) as regards environmental care, referring to safety motivations (Maslow 1970) and aimed at avoiding or eliminating the problem (Fennell 1978; Rossiter and Percy 1987). Likewise, they could be related to the feelings and emotions the consumer experiences when he uses the brand (experiental benefit), such that the consumer's satisfaction increases on believing that, by purchasing the brand, he is contributing to social welfare. Finally, brand-attributed environmental benefits could be related to the needs of social approval or external personal expression (symbolic benefit); in other words, those individuals who consider themselves to be ecologists may consider not purchasing a brand if they feel that it does not adequately reflect their ideology.

At the top of the scale, environmental associations can determine attitudes, these being the consumers' overall evaluation of the brand (Wilkie 1986). The attitudes sum up beliefs regarding the attributes and the functional, experimental and symbolic benefits (Keller, 1993), as well as contributing toward the perception of brand quality (Zeithaml 1988).

Our main hypothesis is that brand associations can refer to the environmental performance of the brand. This is consistent with Keller (1998a) when he points out that the social benefits of the product could be included among the brand associations. Thus, they may help to reinforce the brand image, improve its credibility and promote the feeling of accomplishment or realization on purchasing the product (Hoeffler and Keller 2002). 
If this is the case, environmental associations should improve brand attitude (Kinnear and Taylor 1973), thus contributing to an increase in brand equity (Henion 1972; Louchran and Kangis 1994).

In short, associating ecological attributes with the brand can contribute toward brand differentiation (Gallarotti 1995), which will be viable as long as the environmental advantages are able to justify higher prices and can be communicated to the public (Azzone and Bertelé 1994). Products with clear environmental advantages, accompanied by effective communication channels, will better survive price-induced competition attacks (Kassarjian 1971).

The above reasoning allows us to establish a prior hypothesis, derived from theoretical contributions and empirical studies. The former generically postulate a series of benefits for the brand and/or company arising from developing Corporate Societal Marketing activities (Louchran and Kangis 1994; Keller 1998; Hoeffler and Keller 2002). Secondly, previous studies have already shown the direct link existing between ecological attributes and brand attitude (Kinnear and Taylor 1973), or relating to the ecological attributes of market share (Henion 1972). Therefore, we firstly examine the presence of a direct positive relationship between belief in the environmental performance of the brand and brand attitude:

$\mathrm{H}_{1}$ : The stronger the beliefs regarding the brand's environmental performance, the stronger is brand attitude.

Secondly, some of the literature on environmental purchase behavior demonstrates that ecological attributes are secondary in evaluating purchase alternatives (Stisser 1994; Niva, Heiskanen, and Timonen 1998). To corroborate this hypothesis, we establish that:

$\mathrm{H}_{2}$ : The importance of the ecological attribute in forming attitudes is less than that of attributes related to the functional performance of the brand. 
Thirdly, we understand that, if environmental associations are to be successful, besides there being a consumer consciousness, the consumer also needs guarantees that the product contains the ecological attributes it communicates. Purchase intention, and therefore, brand equity, are negatively affected when an individual feels the environmental claim [2] is lacking in truth (Newell, Goldsmith, and Banzhaf 1998). Meanwhile, when the source has credibility, the individual's behavior becomes more respectful toward the environment (Craig and McCann 1978) and, thus, more inclined to the purchase of environmental products.

Consumers interested in green products are generally skeptical of advertising in general (Shrum, McCarty, and Lowrey 1995), or feel confused about the environmental claims used by firms (Mayer, Scammon, and Zick 1993). This skepticism is mainly produced by the exaggeration of some of the messages used, as well as the lack of a clear meaning in the message and the complexity of the knowledge regarding the effect of the different forms of consumption on the environment (Fay 1992; Carlson, Grove, and Kangun 1993; Scammon and Mayer 1995)

Taking the above into account, and although the skepticism toward environmental claims has been considered to be the consequence of the individual's generally cynical attitude (Mohr, Eroglu, and Ellen 1998), it could be of more use to ratify a product's environmental benefits through an independent body (Scammon and Mayer 1993; 1995).. Therefore:

$\mathrm{H}_{3}$ : Beliefs regarding the ecological performance of the brand are stronger when the environmental performance message is accompanied by an environmental label issued by an independent body.

\section{METHODOLOGY}

Experimental Design 
The hypotheses established required the development of an experimental situation in which the subject was exposed to a stimulus including information on the brand being studied. Thus, we defined three experimental groups, along with one control group in which the relevant characteristics were measured without the group's prior exposition to the treatment. This was in order to isolate the possible influence of the information contained in the message that did not refer to environmental questions (see Table I). A very similar development to this has been previously used by Murphy, Kangun, and Locander (1978).

\section{TAKE IN TABLE I}

The product selected was washing powder, given the easy identification of its negative effects on the environment. This same product has often been used in previous studies as an environmentally-associated object (Henion 1972; Kinnear and Taylor 1973; Mazis, Settle, and Leslie 1973; Brooker 1976; Tucker 1978; Murphy, Kangun, and Locander 1978; Henion, Russell, and Clee 1981; Schuhwerk and Lefkoff-Hagius 1995; Roozen 1997; Niva, Heiskanen, and Tiomnen 1998). The brand chosen had, at the time the study was carried out, the second highest market share, volume-wise, in Spain (8.7\%), which ensured that brand was very well known.

In order to transmit the information, a leaflet specifically designed for the research was used, containing written information and color pictures. Choosing this form of communication is in line with the fact that written matter is the form usually employed to transmit aspects concerning the firm's or the product's ecological image (Banerjee, Gulas, and Iyer 1995).

The information on the environmental performance of the brand was included in the righthand section inside the leaflet (where it was most visible). This information was selected bearing in mind that it is more effective when included as benefits that are supplementary or additional to the main ones (Davis 1993); if it refers to specific actions taken by the 
brand to improve the environment (Thorson, Page, and Moore 1995); if the environmental benefits are evident and accompanied by corporate initiatives (Ottman 1992) and if it includes expectations that the problem is being solved (Ellen, Wiener and Cobb-Walgren 1991; Obermiller 1995). The text included in the leaflet referring to the environmental performance of the product was as follows $\left(\mathrm{INF}_{2}\right)$ :

(BRAND) WITH THE ENVIRONMENT. The tensioactive agents (Brand) used are biodegradable and the average water temperature needed for washing has been reduced. The manufacturing process used for the product has also been improved, resulting in: reduction in pollution, more waste recycling and a lower energy consumption.

The independent certification $\left(\mathrm{INF}_{3}\right)$ was placed on the inside of the front page, using that granted by the Association Internationale de la Savonnerie, de la Dètergence et des Produits d'Entretien (AISE), to all those manufacturers that adopt the principles of the code of "Good environmental practice". In addition to this, a certification was included referring to the compliance with ISO standard 14001, guaranteeing the implementation of environmental management systems, accompanied by a text explaining what the logo actually meant.

Finally, a leaflet was designed containing only performance information $\left(\mathrm{INF}_{1}\right)$. Its design was identical to the two previous ones, except that the space used to include the environmental information contained images.

\section{Measurement Scales}

Once the respondent had seen the leaflet, the relevant measurements were taken. All the scales go from 1 to 5 and are all formulated as semantic differentials. More specifically, brand attitude is measure using a scale of four semantic differentials (Mitchell and Olson 1981): bad-good; poor quality-high quality; unappealing-very appealing; I don't like it-I like it. Brand beliefs are measured using a simple item for each attribute in question form: 
To what extent do you think the brand will probably benefit [get rid of dirt, be ecological, be gentle on laundry]? (completely improbable-completely probable) (Droge and Darmon 1987).

The level of confidence in own judgements is measured by adapting Smith's "confidence in beliefs" scale (Bruner and Hensel 1994). This scale is developed in such a way that, after answering the question on the probability of the brand possessing a certain attribute (brand beliefs), the respondent must determine how convinced she is about the prior judgement (not at all convinced-fully convinced).

Sample

For reasons of convenience, four Spanish cities were selected, being representative of the Spanish socio-demografic profile. In each city a Hall Test was carried out by specialist professionals in market research. Again, for the purpose of operativeness and convenience, it was decided that the sample would be formed solely by over-18-year-old females, given our interest in people who are familiar with the purchase of these products and who are also responsible for the purchase decisions. Studies on the purchase behavior of the Spanish consumer show that there is a clear predominance of women in the purchase of household products (Martínez-Salinas 1996; Luque-Martínez 1998). In 70\% of cases, women are responsible for doing the household shopping and in $78 \%$ of cases for drawing up the list of foodstuffs needed [3]. Age quotas were also established, so as to limit the interviewers' discretionality when collecting the sample elements. Finally, 414 personal interviews were carried out with women who purchased washing powder, distributed by experimental groups as follows: $\mathrm{GE} 1=117$; GE2 $=118$; $\mathrm{GE} 3=117 ; \mathrm{GC}=62$. The data was collected in July 2001.

\section{RESULTS}

Effectiveness of the Experimental Situation 
Confidence in the veracity of one's own judgment on the environmental performance of the brand (CONF_2) was used as a manipulation check, showing significant differences depending on the treatment carried out $(\mathrm{p}=0.02)$. The measurements of CONF_2 $(\mathrm{GE} 1=3.316$; GE2 $=3.585 ; \mathrm{GE} 3=3.767)$ increase in the direction forecasted, demonstrating that both the environmental information $\left(\mathrm{INF}_{2}\right)$ and the environmental label $\left(\mathrm{INF}_{3}\right)$ were perceived by the respondents. However, no significant differences were observed regarding the confidence in the judgements made, on the one hand, on how well the washing powder gets rid of dirt $(\mathrm{p}=0.330)$, and, on the other, on how gentle the washing powder is on laundry $(\mathrm{CONF} 3)(\mathrm{p}=0.112)$ depending on the treatment carried out. Thus, it is revealed that the information levels $\mathrm{INF}_{2}$ and $\mathrm{INF}_{3}$ do not contribute toward improving confidence in judgements made on attributes other than environmental performance.

There were no differences in CONF_2 between GC and GE1 $(\mathrm{p}=0.156)$, showing, therefore, that the generic information $\left(\mathrm{INF}_{1}\right)$ did not affect confidence in the environmental performance of the brand. Likewise, there were no differences between GC and GE1 for CONF_1 $(p=0.076)$ and for CONF_3 $(p=0.967)$. This indicates that the generic information $\left(\mathrm{INF}_{1}\right)$ does not affect confidence in the brand's functional performance.

Finally, the time the respondents were exposed to the message (in seconds) rose significantly $(\mathrm{p}=0.000)$ the more environmental information the leaflet contained $(\mathrm{GE} 1=42.16$; GE2 $=52.27$; GE3=58.45). A summary of the results obtained to evaluate the effectiveness of the experimental situation are included in Table II.

\section{TAKE IN TABLE II}

\section{Evaluation of the Multi-Item Scales Used}

Only one of the concepts included in the analysis was measured using multi-item scales. The brand attitude measurement scale shows an overall alpha value of 0.845 (GE1 $=0.859$; 
GE2 $=0.848$; GE3 $=0.828$ ), taking into account that the last of the four items was worded in the opposite sense to the rest.

Contrasting the Hypotheses

Firstly, in order to test $\mathrm{H}_{1}$, the sample was split into two parts according to the median of the item used to measure beliefs in the brand's ecological performance. One part contained those that presented a low level of beliefs $(n=207)$ and the other part included those with a high level $(n=141)$. To check the presence of differences between both groups, a t-test was used. The results obtained $(\mathrm{t}=5.97 ; \mathrm{p}=0.000)$ ratify the presence of a direct positive relationship between beliefs regarding ecological performance and brand attitude $\left(\mathrm{H}_{1}\right)$ and reveal that brand attitude is greater among those individuals with high beliefs in the brand's ecological performance (mean $=16.390)$ than among those with low beliefs $($ mean $=14.667)$.

Secondly, to test Hypothesis 2, we calculate the correlation coefficients between the three attributes and brand attitude and then we use the test of differences between two correlation coefficients. Thus, empirical support $(\mathrm{p}=0,033)$ is given to the hypothesis regarding the lower effect of beliefs in environmental performance (ATTR_2) when compared with beliefs in the attribute "is gentle on laundry" (ATTR_3), but not $(\mathrm{p}=0,877)$ when compared with beliefs regarding the attribute "gets rid of dirt" (ATTR_1). $\mathrm{H}_{2}$, therefore, should be partially rejected.

Finally, the positive effect of environmental labels on the beliefs regarding the ecological attribute is ratified by an ANOVA test $(\mathrm{F}=3,058 ; \mathrm{p}=0,048)$. Nonetheless, we should point out that the statistically significant differences are achieved solely between the group that did not receive any environmental information (GE1) and the group that received said information along with the environmental label (GE3), but not between GE3 and GE2, nor between GE1 and GE2 [4]. Therefore, within the poor definition of the results obtained, we 
can conclude that, in effect, the only way of increasing beliefs in the environmental performance of the brand is by transmitting environmental associations accompanied by an environmental label. The results of the statistical tests are shown in Table III.

INSERT TABLE III

\section{CONCLUSIONS AND MANAGERIAL IMPLICATIONS}

The results obtained from the simple hypothesis tests reveal a direct positive relationship between the beliefs regarding the ecological performance of the brand and attitude toward said brand. Likewise, relative evidence has been found to support the hypothesis of the lower importance of the ecological attribute compared to other attributes. These results are, to some extent, incongruous with those obtained after testing an environmental information-processing model, which has revealed the lack of statistic relevance of the effect of such beliefs on brand attitude.

This conclusion contradicts, therefore, some other empirical contributions in this field (e.g. Henion 1972; Kinnear and Taylor 1973), although the methodology and objectives of these two studies are very different to those established for this research. On the other hand, it is in keeping with those studies that have demonstrated the secondary role of these associations compared to others (Stisser 1994; Niva, Heiskanen, and Timonen 1998).

Nonetheless, these results do allow us to recommend the use of environmental associations (we should not forget the positive correlation existing between beliefs regarding the ecological performance of the brand and attitude toward said brand), though they do suggest that these associations never overshadow those others that the consumer considers to be principal in each product category.

On another note, we have found that environmental labels help to strengthen beliefs regarding the environmental performance of the brand, as well as increasing confidence in 
the judgments made on said performance. This main contribution is in line with other studies that have suggested that environmental labels should have a positive influence on the consumer's evaluations of the environmental performance of the brands included in the research (Parkinson 1975; Scammon and Mayer 1993, 1995; Roe et al. 2001), though, as far as we know, this relationship had not been experimentally proved.

In this sense, we believe there is a need to homogenize the environmental labeling programs, which will help to reduce the risk perceived in the evaluation of said performance. There should also be a greater effort made by public administrations to inform the citizen of the existence of such labels, of their meaning and of the methodology used in granting them. For all of this, a useful way forward would be to intensify the presence of commissions, promoted by international bodies, in which the scientific community, ecology groups, certifying organizations, firms and the consumers themselves would all have their role.

\section{FUTURE RESEARCH}

The research work presented here should, in the future, be extended, by analyzing the convenience of implementing a single certifying system. This would be common to all product categories and, if useful, would contribute greatly toward communication with the general public. This possibility could also be replicated in other product categories, particularly durable goods, where involvement is normally higher. Another area could be that of services, in which it is more difficult to define a brand's environmental benefits.

\section{ENDNOTES}

[1] Monitor Global International 2001. Quota Unión. Available at http://www.fundacionentorno.org

[2] We understand environmental claims to be the declaration made by a seller that refers to the impact of one or more of his brand's attributes on the natural environment (Scammon and Mayer 1995).

[3] According to the study "The Role of the Woman in Food", carried out by the Omega 3 Institute. Press review in elmundo.es (July 2003). Available at http://www.elmundo.es/elmundo/2003/07/14/sociedad/1058184716.html.

[4] p values for the Tukey Test (HSD): GE1 vs. GE3=0.279; GE1 vs. GE3=0.039; GE2 vs. GE3=0.625. 


\section{REFERENCES}

Aaker, D. A. (1992), “The Value of Brand Equity”, Journal of Business Strategy, Vol 13 No 4, pp. 27-33.

Azzone, G.and Bertelé, U. (1994), "Exploiting Green Strategies for Competitive Advantage", Long Range Planning, Vol 27 No 6, pp. 69-81.

Banerjee, S.; Gulas, C.S. and Iyer, E. (1995), "Shades of Green: A Multidimensional Analysis of Environmental Advertising", Journal of Advertising, Vol 24 No 2, pp. 21-31.

Brooker, G. (1976), "The Self-Actualizing Conscious Consumer", Journal of Consumer Research, Vol 3 (September), pp. 107-112.

Bruner, G. C. and Hensel, P. (1994), Marketing Scales Handbook: A Compilation of MultiItem Measures, AMA, Chicago.

Carlson, L.; Grove, S.J.; and Norman Kangun (1993), "A Content Analysis of Environmental Advertising Claims: A Matrix Method Approach", Journal of Advertising, Vol 22 No 3, pp. 27-39.

Craig, C. S.; and McCann, J.M. (1978), "Assessing Communication Effects on Energy Conservation", Journal of Consumer Research, Vol 5 (September), pp. 82-88.

Davis, J. J. (1993), "Strategies for Environmental Advertising", Journal of Consumer Marketing, Vol 10 No 2, pp. 19-36.

Dröge, C.; and Darmon, R.Y. (1987), "Associative Positioning Strategies Through Comparative Advertising: Attribute versus Overall Similarity Approaches", Journal of Marketing Research, Vol 24 (November), pp. 377-388.

Ellen, P. S.; Wiener, J.L. and Cobb-Walgren, C. (1991), "The Role of Perceived Consumer Effectiveness in Motivating Environmentally Conscious Behaviours", Journal of Public Policy and Marketing, Vol 10 No 2, pp. 102-117.

Fay, W. B. (1992), “The Environment's Second Wave”, Marketing Research (December): 4445.

Fennell, G. (1978), “Consumers' Perceptions of the Product-Use Situation", Journal of Marketing, Vol 42 No 2, pp. 38-47.

Gallarotti, G. M. (1995), "It Pays to Be Green: The Managerial Incentive Structure and Environmentally Sound Strategies", The Columbia Journal of World Business, (Winter), pp. 39-57.

Henion, K. E. (1972), “The Effect of Ecologically Relevant Information on Detergent Sales”, Journal of Marketing Research, Vol 9 No 1, pp. 10-14.

Henion, K. E.; Russell, G. and Clee, M.A. (1981), "Trade-Offs in Attribute Levels Made by Ecologically Concerned and Unconcerned Consumers When Buying Detergents", Advances in Consumer Research, Vol 8, pp. 624-629.

Hoeffler, S. and Keller, K.L. (2002), "Building Brand Equity trough Corporate Societal Marketing”, Journal of Public Policy \& Marketing, Vol 21 No 1, pp. 78-89.

Kassarjian, H. H. (1971), "Incorporating Ecology into Marketing Strategy: The Case of Air Pollution", Journal of Marketing, Vol 35 (July), pp. 61-65.

Keller, K. L. (1993), “Conceptualizing, Measuring and Managing Customer-Based Brand Equity", Journal of Marketing, Vol 57 (January), pp. 1-22.

Keller, K. L. (1998a), "Branding Perspectives on Social Marketing", Advances in Consumer Research, Vol 28, pp. 299-302.

Keller, K. L. (1998b), Building, Measuring, and Managing Brand Equity, Prentince-Hall, Eglewood Cliffs (NJ).

Kinnear, T. C. and Taylor, J. (1973), "The Effect of Ecological Concerns on Brand Perceptions”, Journal of Marketing Research, Vol 10 (May), pp. 191-197. 
Louchran, V. and Kangis, P. (1994), "Gift Packaging in Duty Free Markets. Environmentalism and Brand Equity", Journal of Product \& Brand Management, Vol 3 No 3, pp. 5-7.

Luque-Martínez, T. (1998), Comercio Minorista y Comportamiento del Consumidor Granadino. Camara de Comercio, Industria y Navegación de Granada,Granada (Spain):.

Martínez-Salinas, E. (1996), Tipología de las Decisiones Familiares: El Papel de los Cónyuges. VIII Encuentro de Profesores Universitarios de Marketing. ESIC, Madrid.

Maslow, A. (1970), Motivation and Personality, Harper \& Row Publishers, New York.

Mayer, R. N.; Scammon, D.L. and Zick, C.D. (1993) "Poisoning the Well: Do Environmental Claims Strain Consumer Credulity?", Advances in Consumer Research, Vol 20, pp. 698-703.

Mazis, M. B., Settle, R.B. and Leslie, D. (1973), "Elimination of Phosphate Detergents and Psychological Reactance", Journal of Marketing Research, Vol 10 (November), pp. 390-395.

Mitchell, A. A. and Olson, J.C. (1981), "Are Product Attribute Beliefs the Only Mediators of Advertising Beliefs on Brand Attitude?", Journal of Marketing Research, Vol 18 (August), pp. 318-332.

Mohr, L. A.; Eroglu, D. and Ellen, P.S. (1998), "The Development and Testing of a Measure of Skepticism toward Environmental Claims in Marketer's Communications", Journal of Consumer Affairs, Vol 32 No 1, pp. 30-55.

Murphy, P. E.; Kangun, N. and Locander, W.B. (1978), "Environmentally Concerned Consumers-Racial Variations", Journal of Marketing, Vol 42 (October), pp. 61-66.

Newell, S. J.; Goldsmith, R.E. and Banzhaf, E.J. (1998), "The Effect of Misleading Environmental Claims on Consumer Perceptions of Advertisements", Journal of Marketing Theory \& Practice, (Spring), pp. 48-60.

Niva, M.; Heiskanen, E. and Timonen, P. (1998), "Consumer's Environmental Sophistication, Knowledge, Motivation and Behaviour", European Advances in Consumer Research, Vol 3, pp. 321-327.

Obermiller, C. (1995), “The Baby Is Sick/The Baby Is Well: A Test of Environmental Communication Appeals", Journal of Advertising, Vol 24 No2, pp. 55-70.

Ottman, J. A. (1992) "Industry's Response to Green Consumerism", Journal of Business Strategy, Vol 13 No 4, pp. 3-7.

Park, C. W.; Jaworski, B. and Macinnis, D.J. (1986), "Strategic Brand Concept-Image Management", Journal of Marketing, Vol 50 (October), pp. 135-145.

Parkinson, T. L. (1975), "The Role of Seals and Certifications of Approval in Consumer Decision Making", Journal of Consumer Affairs, Vol 9 No 1, pp. 1-14.

Roe, B.; Teisl, M. F.; Rong, H. and Levy, A.S. (2001), "Characteristic of ConsumerPreferred Labeling Policies: Experimental Evidence from Price and Environmental Disclosure for Deregulated Electricity Services", Journal of Consumer Affairs, Vol 35 No 1, pp. 1-26.

Rossiter, J. R. and Percy, L. (1987), Advertising and Promotion and Management. McGrawHill, New York:.

Roozen, I. T. M. (1997), "Who Are Really Purchasing Environmentally Friendly Detergents?", Journal of Consumer Studies and Home Economics, Vol 21, pp. 237-245.

Scammon, D. L. and Mayer, R.N. (1993), "Environmental Labeling and Advertising Claims: International Action and Policy Issues", European Advances in Consumer Research, Vol 1, pp. 338-344

Scammon, D. L. and Mayer, R.N. (1995), "Agency Review of Environmental Marketing Claims: Case-by-Case Decomposition of the Issues", Journal of Advertising, Vol 24 No 2, pp. 33-43.

Schuhwerk, M. E. and Lefkoff-Hagius, R. (1995), "Green or Non-Green? Does Type of Appeal Matter When Advertising a Green Product?”, Journal of Advertising, Vol 24 No 2, pp. 45-54. 
Sheth, J. N. and Sidosia, R.S. (1999), "Revisiting Marketing's Lawlike Generalizations", Journal of the Academy of Marketing Science, Vol 27 No 1, pp. 71-87.

Shrum, L. J.; McCarty, J.A. and Lowrey, T.M. (1995), "Buyer Characteristics of the Green Consumers and Their Implications for Advertising Strategy", Journal of Advertising, Vol 24 No2, pp. 71-82.

Stisser, P. (1994), “A Deeper Shade of Green”, American Demographics, Vol 16 No3, pp. 2429.

Thorson, E.; Page, T. and Moore, J. (1995), "Consumer Response to Four Categories of "Green" Television Commercials", Advances in Consumer Research, Vol 22, pp. 243-250.

Tucker, L. R. (1978), "The Environmentally-Concerned Citizen: Some Correlates", Environment \& Behavior, Vol 10 No 3, pp. 398-418.

Wilkie, W. L. (1986), Consumer Behavior, John Wiley \& Sons, New York.

Van Osselaer, S. M. J., and Janiszewski, C. (2001), "Two Ways of Learning Brand Associations", Journal of Consumer Research, Vol 28 (September), pp. 202-223.

Zeithalm, V. A. (1988), "Consumer Perceptions of Price, Quality, and Value: a Means Model and Synthesis Evidence”, Journal of Marketing, Vol 52 No 3, pp. 2-22. 
TABLE I: Experimental Design and Treatment

\begin{tabular}{|c|c|c|c|}
\hline \multicolumn{4}{|c|}{ Group Description } \\
\hline GE1 & \multicolumn{3}{|c|}{ Generic information on the brand ( $\left.\mathrm{INF}_{1}\right)$} \\
\hline GE2 & \multicolumn{3}{|c|}{$\left(\mathrm{INF}_{1}\right)+$ information on the environmental performance of the brand $\left(\mathrm{INF}_{2}\right)$} \\
\hline GE3 & \multicolumn{3}{|c|}{$\left(\mathrm{INF}_{1}\right)+\left(\mathrm{INF}_{2}\right)+$ environmental label $\left(\mathrm{INF}_{3}\right)$} \\
\hline $\mathrm{GC}$ & \multicolumn{3}{|c|}{ No information } \\
\hline \multicolumn{4}{|c|}{ TABLE II: Evaluation of the Experiment's Effectiveness } \\
\hline \multicolumn{2}{|c|}{ Manipulation Check } & $\mathrm{F} ; \mathrm{t} ;$ (g.1.); p & Result \\
\hline \multicolumn{2}{|c|}{$\begin{array}{l}\text { Differences in CONF_2 } \\
\text { among GE1; GE2; GE3 }\end{array}$} & $\begin{array}{l}6,058 ;(2 ; 348) \\
0,002\end{array}$ & $\begin{array}{l}\text { Positive effect of the levels of information } \\
\text { supplied on the confidence in own judgements } \\
\text { regarding the brand's environmental } \\
\text { performance (mean INF } 1=3.316 \text {; INF2 }=3.585 \text {; } \\
\text { INF3=3.767) }\end{array}$ \\
\hline \multirow{2}{*}{\multicolumn{2}{|c|}{$\begin{array}{l}\text { Differences in CONF_1 } \\
\text { among GE1; GE2; GE3 }\end{array}$}} & 1,$112 ;(2 ; 348)$ & No significant effect of the levels of \\
\hline & & 0,330 & information supplied on the confidence in own \\
\hline \multirow{2}{*}{\multicolumn{2}{|c|}{$\begin{array}{l}\text { Differences in CONF } 3 \\
\text { among GE1; GE2; GE3 }\end{array}$}} & 2,$201 ;(2 ; 348)$ & judgements regarding how well the brand works \\
\hline & & 0,112 & (different from environmental performance) \\
\hline \multicolumn{2}{|c|}{$\begin{array}{l}\text { Differences in CONF_1 } \\
\text { among GC y GE1 }\end{array}$} & $\begin{array}{l}-1,786 ;(174) \\
0,076\end{array}$ & $\begin{array}{l}\text { No significant effect of taking part in the } \\
\text { experiment on the confidence in own }\end{array}$ \\
\hline \multicolumn{2}{|c|}{$\begin{array}{l}\text { Differences in CONF_2 } \\
\text { among GC y GE1 }\end{array}$} & $\begin{array}{l}-1,425 ;(175) \\
0,156\end{array}$ & $\begin{array}{l}\text { judgements regarding the three attributes } \\
\text { considered }\end{array}$ \\
\hline \multicolumn{2}{|c|}{$\begin{array}{l}\text { Differences CONF_3 } \\
\text { among GC y GE2 }\end{array}$} & $\begin{array}{l}-0,041 ;(175) \\
0,967\end{array}$ & \\
\hline \multicolumn{2}{|c|}{$\begin{array}{l}\text { Differences in exposure } \\
\text { time to treatment among } \\
\text { GE1; GE2; GE3 }\end{array}$} & $\begin{array}{l}8,231 ;(2 ; 343) \\
0,000\end{array}$ & $\begin{array}{l}\text { Greater exposure time the more information } \\
\text { supplied (mean INF } 1=42.159 ; \quad I N F 2=52.276 \text {; } \\
\text { INF3 }=58.453)\end{array}$ \\
\hline
\end{tabular}

TABLE III Results of the Hypothesis Tests

\begin{tabular}{|c|c|c|c|}
\hline & Test Used & $\mathrm{p}$ & Result \\
\hline \multirow[t]{2}{*}{$\mathrm{H}_{1}$} & $\begin{array}{l}\text { Difference of means test for } \\
\text { attitude toward the brand (ATB) } \\
\text { among individuals with high } \\
\text { (ATTR_2>Median) and low } \\
\text { (ATTR_ } 2<=\text { Median) levels of } \\
\text { belief regarding brand performance }\end{array}$ & 0.000 & 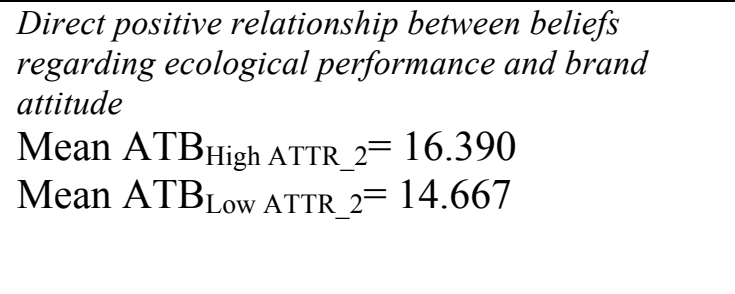 \\
\hline & $\begin{array}{l}\text { Difference between correlation } \\
\text { coefficients test: ATTR_1 } 1 \rightarrow \text { ATB } \\
\text { v. ATTR_2 } \rightarrow \text { ATB }\end{array}$ & 0.877 & $\begin{array}{l}\text { The effects of ATTR_1 and ATTR_2 on brand } \\
\text { attitude are statistically equal } \\
\text { Correlation } \\
\text { CorTR_1 } 1 \rightarrow \mathrm{ATB}=0.39 \\
\text { Correlation }_{\text {ATTR } 2 \rightarrow \mathrm{ATB}}=0.38\end{array}$ \\
\hline $\mathrm{H}_{2}$ & $\begin{array}{l}\text { Difference between correlation } \\
\text { coefficients test: ATTR_3 } \rightarrow \text { ATB } \\
\text { v. ATTR_2 } \rightarrow \text { ATB }\end{array}$ & 0.033 & $\begin{array}{l}\text { The effect of ATTR } 3 \text { on brand attitude is } \\
\text { greater than that of ATTR_2 } \\
\text { Correlation } \\
\text { ATTR_3 } \rightarrow \text { ATB }=0.51 \\
\text { Correlation } \\
\text { ATTR_2 } 2 \rightarrow \text { ATB }_{1}=0.38\end{array}$ \\
\hline $\mathrm{H}_{3}$ & $\begin{array}{l}\text { ANOVA. Dependent variable } \\
\text { ATTR_2; independent variable } \\
\text { level of experimental treatment }\end{array}$ & 0.048 & $\begin{array}{l}\text { There is a direct effect of the environmental labels } \\
\text { on the beliefs regarding the ecological attribute } \\
\text { Mean ATTR_2 } 2_{\mathrm{GE} 1}=3.078 \\
\text { Mean ATTR_2 } 2_{\mathrm{GE} 2}=3.265 \\
\text { Mean ATTR_2 } 2_{\mathrm{GE} 3}=3.379\end{array}$ \\
\hline
\end{tabular}

